\title{
TRANSLATION OF WORDS REPRESENTING THE AUTISTIC CHARACTER IN FLOWERS FOR ALGERNON NOVEL
}

\author{
Trisakti Agriani \\ saktitititi@gmail.com \\ MR Nababan \\ amantaradja.nababan_2017@staff.uns.ac.id \\ Djatmika \\ djatmika@staff.uns.ac.id \\ Universitas Sebelas Maret Surakarta
}

\begin{abstract}
This study was aimed at analyzing the Indonesian translation of spelling, punctuation, and grammatical errors made by autistic character in Flower for Algernon novel. It also analyzes translation techniques, methods, ideology, qualities of the translation. The method applied was descriptivequalitative with the data in the form of translated words and phrases indicating spelling, punctuation and grammatical errors made by the autistic character. The primary data sources were Flower for Algernon novel along with its translation version in Indonesian. Meanwhile, the secondary data sources were informants who gave information on the accuracy, acceptability, and readability of translation. The process of collecting data used documentation, questionnaire distribution, and focus group discussion (FGD) technique whereas the sampling technique applied is purposive sampling. The findings of this research show that there are 309 data of words containing spelling, punctuation and grammatical errors. Four translation techniques are used by translator namely graphology normalizations, established equivalent, compensation, and deletion. The translation method used tends to be established equivalent with domestication ideology. The translation of words with errors by graphology normalization techniques produced accurate translations with decreases in acceptability. This is because the translator removes the autism markers from the source language to the target language.
\end{abstract}

Key words: autism, translation techniques, errors, character

\section{INTRODUCTION}

Nowadays, especially in globalization era, communications in different languages is very important. They allow ideas and information to spread accross cultures. Therefore, there needs to be someone to translate the different languages so that people can officially understand one another, with the meaning distinctly clear and succint. Wiratno (2003) states that translation is a process of transferringmessage from the source language (SL) to the target language (TL). SL is the origin language which is translated, while TL is the destination language used to express the result of translation. Meanwhile,
Nida \& Taber in Munday (2001, 40) divide the process of translating into three stages, namely: analysis of message in SL, transfer, and reconstruction of the transferred message in TL.

Translation is not easy, it can be difficult to establish its equivalencefor example from English to Indonesian or vice versa-since they have different grammatical systems and structures. The system and structure of SL and TL may become the obstacles if the translator faces difficulties to discover the equivalence of both languages. Nida \& Taber $(1982,12)$ state that translation consists in reproducing in the receptor 
language the closest natural equivalent of the source language message, first in terms of meaning and secondly in terms of style. Based to the definition, translating means transferring the message from SL into TL. The message in TL should have equivalence or close meaning to the SL. In conclusion, meaning is more important than style in translation.

In the process of translation, translators usually use some procedures to solve the specific translation problems. There have been overlapping terms to refer to the procedures, such as 'translation method' and 'translation strategy' as proposed by some translation experts which were then reviewed and revised by Molina \& Albir $(2002,449)$ to get a better classification consistent in its application and were meant to reach all kinds of texts. Molina \& Albir proposed the term 'translation technique' and defined it as 'a procedure for analyzing and classifying an effort to achieve translation equivalence'.

In this research, the writer analyzed and classified the translation techniques applied in Flowers for Algernon novel by using Molina \& Albir's theory. According to Molina \& Albir (2002, 510-511), there are 18 kinds of translation techniques, namely: adaptation, amplification, borrowing, calque, compensation, description, discursive creation, established equivalence, generalization, linguistic amplification, linguistic compression, literal translation, modulation, particularization, reduction, substitution, transposition, and variation.

A good translation has to transfer the message from source language to target language very well. The readers sometimes only read the translation product without paying attention to the translation quality. Translation quality assessment is very important for translation product. Translation quality assessment is an activity to give value to a translation product whether the product is having good quality or not. Furthermore, assessing or criticizing a translation is not easy because it needs an extraordinary ability (Nababan 2003). A translation product is not always perfect. Sometimes there are many mistakes in the translation product when it is compared to the original one. Assessment towards translation quality focuses in three things namely accuracy, acceptability, and readability.

Spelling is an important aspect of language knowledge; it is a key functional component of writing. In other words, spelling is the key to both reading and writing of a language,which means that effective writing depends on effective spelling. Poor spelling can interfere with communication between the writer and the reader (Smedley 1983, Moseley 1993, Brann 1997, Willett 2003)

Ida (2006) states that English spelling is unquestionably a difficult and complex matter and learners around the world have difficulty getting the letters right. As stated by Fay (1971), English spelling is characterized by the inconsistencies of pronunciations, as well as by the discrepancies in the numbers and combinations of letters used to represent English sounds. Meanwhile, spelling error can be defined as an error in the conventionally accepted form of spelling a word (Collins 2013).

Flowers for Algernon was written in the style of a diary by Charlie, the main character in the novel. The early parts of the novel contain reports in a ragged style, full of spelling, punctuation, and grammar mistakes because the main actor in this novel has an autism spectrum disorder, in which he cannot write perfectly. As the story, these reports evolve with grammatical improvements, writing styles, and mindsets. At the end of this novel plot, spelling, punctuation and 
grammatical errors reappear in this novel.

The sample of the data found in this novel is as follow:

SL: I said okay and Prof Nemur showed me how to werk the TV that reely wasnt a TV. I askd him what did it do. First he look sore again because I asked him to explane me and he said I shoud just do what he told me. But Dr Strauss said he shoudexplane it to me because I was beginning to question authorety. I dontno what that meens but Prof Nemur looked like he was going to bite his lip off.Then he explaned me very slow that the mashine did lots of things to my mind. Somethings it did just before I fall asleep like teach me things when Imvery sleepy and a little while after I start to fall asleep I still hear the talk even if I dont see the picturs anymore. Other things is at niteits suppose to make me have dreams and remembir things that happened a long time ago when I was a very little kid.Its scary.

TL: Aku bilang oke dan Prof Nemur memperlihatkan padaku bagaimana $T V$ yang bukan TV sebenarannya itu bekreja. Aku tanya padanya apa gunanya. Pertama-tama ia tumpak cemberut karena aku minta penjlasan padanya dan ia bilang aku hanya harus melakukan apa yang dikatakannya. Tapi Dr Strauss bilang ia harus menjlaskannya padaku karena aku mulai mempertanyakan otoritas. Akutidak tau apa atrinya tapi Prof Nemur kelihatan seperti akan menggigit putus bibirnya. Lalu ia menjlaskan padaku dengan lambat sekali bahwa mesyin itu bisa melakukan banyak hal pada pikiranku. Sesuatu akan terjadi sebelum aku tertidur seperti mengajariku hal-hal ketika aku sangat mengantuk dan sejenak sebelum aku betul-betul tertidur aku masih bisa mendengar percakapan bahkan ketika aku tidak lagi melihat gambarnya. Hal lainnya terjadi pada malam hari dan akan membuatku bermimpi dan inggat hal-hal yang terjadi pada masa silam ketika aku masih kecil. Menakutkan.
The fragmentation of the novel in both languages indicates the decrease in the level of acceptability, for example the word 'askd' is meant to be 'asked' which means bertanya in bahasa Indonesia. However, in its translation it translates to tanya, in which the translator eliminates the element of spelling errors in TL text. Another example found in datum above is the existence of the phrase 'the picturs' which contains ommisions type of spelling errors. However, this is omitted by the translator in TL into gambarnya which shows that the translation does not contain any spelling errors at all. In this case it appears that the translator decides to eliminate the misspelling that represents the condition of autism in the main character in this novel. Given the importance of analyzing some words and phrases that represent the author's condition in this novel, the researcher decides to examine the techniques, methods, and ideology implemented in the translation and their impacts on the translation quality of words containing mispellings in the novel.

\section{RESEARCH METHOD}

The method applied in this research was descriptive-qualitative. According to Sutopo $(2002,35)$, in qualitative research, the data collected are in the forms of words, sentences or pictures which has meanings rather than numbers or frequencies. All of the data in this research were in the forms of words or phrases. This research belonged to descriptive-qualitative method because the process of this research was done by collecting the data, analyzing them, and writing the result. In addition to that, this research can be embedded to case study.

This research was descriptive because it was not experimental, and it described phenomena from the beginning to to the end. In addition, this study was a case study and only the researcher could determine whether or not the data could be used in the 
research. Furthermore, the researcher also used purposive or theoretical sampling, to select the appropriate data. The analysis in this research was done inductively (from specific to general) in which any data encountered next were then analyzed. In addition, this research also followed grounded and apriory theory, that is using existing theory as an introduction in conducting research in the field. Besides, this research applied an emergence research design as well, which means it was loose and could change in the middle of its writing process. The results of a descriptive study are based on negotiation with the context and cannot be generalized (Lincoln \& Guba in Santosa 2014). This research was conducted within the field of product-oriented translation as proposed by Nababan (2008, 16) because it used data derived from translations of words and phrases containing spelling, punctuation, and grammatical errors in the Indonesian version of Flowers for Algernon novel.

In this research, the sources of data consisted of documents and informants which were selected by purposive sampling technique. The documents were the novel entitled Flowers for Algernon and its Indonesian translation version. The data were the words that contain spelling, punctuation, and grammatical errors/mistakes in the novel that had been checked by a validator and the scores and descriptions of the translation quality given by raters. Here, the informants comprised a validator and three raters. The techniques of collecting data were document analysis, questionnaire, and focus group discussion. The data were then analyzed by using ethnography method composed by Spradley (2002).

This research implemented two types of questionnaire, close format and open-ended format. The close format questionnaire means that the questionnaire is in form of scaled questionnaire. The researcher distribu- ted questionnaires containing the scale of the translation's accuracy, acceptability, and readability to the raters. Meanwhile, in open-ended format, the raters were allowed to give their comments dealing with the translation's accuracy, acceptability, and readability. The questionnaires containing scales of accuracy, acceptability, and readability were distributed to the raters.

A translation is said accurate when the meanings of SL sentences are accurately conveyed into the target language text, and there is no meaning distortion. Meanwhile, a translation is less accurate is when the meanings of SL sentences are less accurately conveyed into the target language and there are some meaning distortions. Lastly, an inaccurate translation is when the meanings of the source language sentences are not accurately conveyed into the target language. In other words, some of the meanings are omitted or deleted.

Dealing with acceptability, Nagao, Tsuji \& Nakamura in Nababan (2004, 4) state that a translation is acceptable when the SL sentences are translated naturally and it does not feel like a translation product. There is no grammatical mistake and the terms of SL are suitable with the culture of target language. On the other hand, a translation is said less acceptable when it sounds natural enough but still feels like a translation. It is rather clumsy and not in accordance with the language system and culture of TL. Finally, an unacceptable translation extremely sounds like a translation. it is unnatural and clumsy as well as not grammatically and culturally accepted.

Regarding the aspect of readability, Machali (2000, 119-120) defines a translation product as readable when the target language text is fully comprehensible and the readers only need to read it once. Meanwhile, a translation is less readable if there is one or more unfamiliar words found in 
TL text. However, the reader still manages to understand the contents of the text by reading it more than once. Lastly, an unreadable translation is when the reader completely does not comprehend the contents of the TL text. (Richard et al in Nababan 1999, 62).

In this research, to obtain the validity of the data the researcher applied triangulation techniques. By data source triangulation, the researcher used multiple data collections, so that the data and their sources are considered in the study of translation. The multiple sources applied in this case were documents and informants (raters). Through methodological triangulation, the researcher utilized more than one method for gathering data such as: analyzing documents and distributing questionnaire to assess the quality of translation which covers accuracy, acceptability, and readability.

The process of data analysis in this research was organized in the following procedures:

1. Reading Flowers for Algernon novel and its translation and understanding what problems occured in the translation

2. Collecting the data of spelling, punctuation, and grammatical errors.

3. Applying the data coding. Each datum is given number to make it easier to analyze

4. Analyzing the translation techniques

5. Making a list of data in the form of questionnaire

6. Distributing questionnaire to the raters

7. Doing interviews with the respondents

8. Analyzing the data to find out the impacts of the translation techniques toward the quality of the translation in terms of accuracy, acceptability, and readability

9. Drawing conclusions.
The TeChNiQUes AND QUALITIES OF FLOWERS FOR ALGERNON NOVEL TRANSLATION

The result of analysis shows that the words that represent autism spectrum disorder character in the Flowers for Algernon novel were translated into Indonesian using four techniques, namely established equivalent, graphology normalization, compensation and deletion. It can be seen in Table 1.

\section{Translation by Graphology Normalization}

\section{Spelling error type 1}

SL : Dr. Strauss says I shoudrite down what I think and remembir and evrey thing that happins to me from now on.

TL : Dr. Strauss bilang aku harusnulis apa yang kupikir dan kuingat serta segla yang terjadi padaku mulai sekarang dan seterusnya.

In this finding, the translator uses a strategy called graphology normalization in which the words that mark the autistic character are eliminated to be like a normal human beings. Thus, this makes the level of acceptance of this translation decreases yet the level accuracy and the readability of it becomes high.

The word 'shoud' appears in the sentence above which contains a spelling error in SL. However in its TL, the translator removes the element of this spelling error and translates into the word harus which does not contain any spelling error. Therefore, this translation technique uses graphology normalization techniques in which words that contain spelling errors in SL as the marker of the autistic character are made right in terms of spelling. This causes the acceptance of this translation decreasing because in terms of its form, this word, as the marker of autistic character, is omitted by the translator.

\section{Spelling error type 2}

SL : He had a wite coat like a docter but I dont think he was no docter because 
he dint tell me to opin my mouth and say ah.

TL : Ia pake jas puith seperti doktre karena ia tidak bilang sama aku buka mulut dan bilang aaa....

In the above word example there is the word 'opin' which means 'open'. However, in this case the translator omits the autism marker form by being replaced it in TL to buka which the does not contain any spelling error. In this
In this word, there is a translation technique of graphology normalization in the word 'dint' which contains a spelling error meaning 'didn't'. However, in TL the translator translates it into the word 'tidak' which does not contain any spelling error at all. This type of spelling error appears in 20 data which use graphology normalization techniques.

Table 1. Frequency of Translation Techniques

\begin{tabular}{|c|c|c|c|c|}
\hline No & Type of Mistake & Translation Technique & Subtotal & Percentage \\
\hline \multirow[t]{4}{*}{1} & Spelling Error & Graphology Normalization & 81 & $26.21 \%$ \\
\hline & Type 1 & Established Equivalent & 104 & $33.3 \%$ \\
\hline & & Compensation & 8 & $2.6 \%$ \\
\hline & & Deletion & 2 & $0.64 \%$ \\
\hline \multirow[t]{3}{*}{2} & Spelling Error & Graphology Normalization & 21 & $6.79 \%$ \\
\hline & Type 2 & Established Equivalent & 28 & $9.06 \%$ \\
\hline & & Compensation & 1 & $0.32 \%$ \\
\hline \multirow[t]{4}{*}{3} & Spelling Error & Graphology Normalization & 20 & $6.47 \%$ \\
\hline & Type 3 & Established Equivalent & 27 & $8.73 \%$ \\
\hline & & Compensation & 3 & $0.97 \%$ \\
\hline & & Deletion & 1 & $0.32 \%$ \\
\hline \multirow[t]{2}{*}{4} & Punctuation Error & Established Equivalent & 2 & $0.64 \%$ \\
\hline & & Compensation & 1 & $0.32 \%$ \\
\hline \multirow[t]{5}{*}{5} & Grammatical & Graphology Normalization & 5 & $1.61 \%$ \\
\hline & Error & Established Equivalent & 1 & $0.32 \%$ \\
\hline & & Compensation & 1 & $0.32 \%$ \\
\hline & & Deletion & 3 & $0.97 \%$ \\
\hline & \multicolumn{2}{|c|}{ Total } & 309 & $100 \%$ \\
\hline
\end{tabular}

translation, the word is made correct in terms of spelling by the translator. This causes the level of acceptability of this translation to be less acceptable. This translation technique appears in as many as 20 words. This case is not as many as the spelling errors type 1 whose total data is 81 words.

Spelling error type 3

SL : I told them I dint spill the ink on them and I coudnt see anything in the ink.

TL : Aku bilang sama mereka aku tidak menmpahakan tinta di atas kartukartu itu dan aku tidak bisa meliat apa-apa dalam tinta itu.

\section{Grammatical error}

SL : I dint understand about it but I remembir Dr Strauss said do anything the test or telld me even if it dont make no sense because that's testing.

TL : Aku tidak mengerti itu tapi aku inggat Dr Strauss bilang aku harus lakukan apa saja yang diprintah penguji padaku walau itu tidak masuk akal karena itu ujian.

In this datum, there is a grammatical error in terms of subject and verb agreement. It lies in the word 'don't' which should be written 'doesn't' because the subject in the sentence is 
'it'. However, this translation has a diminished acceptance score. This is because the translator applies the graphology normalization technique which results in the loss of the word that represents autism marker that is translating 'it' to tidak in TL.

\section{Translation by Established Equivalent}

Spelling error type 1

SL : My name is Charlie Gordon I werk in Donners bakery where Mr Donner gives me 11 dollers a week and bred or cake if I want.

TL : Namaku Charlie Gordon. Aku kreja di toko kwe Donners. Pak Donners menggajiku 11 dolar tiap minggu ditambah roti atau kwe jika aku mau.

In the above sentence example, there is the word 'werk' which means 'work' and this word contains spelling error. Then, in that word, the translator successfully maintains it in TL into kreja which also contains a spelling error. Hence, this translation is considered to have high accuracy and acceptance. The technique used is established equivalent, because the translator successfully maintains the word representing the autistic character into the target language.

\section{Spelling error type 2}

SL : I dint know what he was gonna do and I was holding on tite to the chair like sometimes when I go to a dentist onley Burt aint no dentist neither but he kept telling me to rilax and that gets me skared because it always means its gonna hert.

TL : Aku tidak tahu apa yang akan dilakukannya dan aku pegangan kursi kuwat kuwat seperti waktu aku ke doktre gigi. Namun Burt bukan doktre gigi juga tapi ia terus-terusan bilang padaku untuk santei dan itu malah bikin aku ktakutan karena itu artinya pasti selalu akan syakit.

This translation uses established equivalent translation techniques which have good translation quality in terms of accuracy, acceptability and readability. In this data, there is the word 'skared' which means 'scared'. The translator here succeeds in defending the word of autism marker into ktakutan in TL which causes this translation to have a good translation quality. In this spelling error type 2, there are 28 words using this translation technique.

Spelling error type 3

SL : So I tolld him it was a very nice pictur of ink with pritty points all around the eges but he shaked his head so that wasnt it neither.

TL : Jadi aku bilang sama Burt itu gmabar tinta yang sangat bagus sekali karena ada titik-titik centik di setiapsudutnya tapi ia menggelengkan kepalanya jadi bukan itu juga.

This translation uses established equivalent technique, that is the word 'pritty' which means 'pretty' and contains the spelling error type 3. It has been maintained into centik in the target language which also marks an autistic character. Since this translation uses established equivalent, it can create an accurate and acceptable translation. In this research, there are 27 words that represent this technique.

\section{Punctuation error}

SL : I think in brooklin.

TL : Kurasa di brooklin.

In this word there is the word 'brooklin' which means 'Brooklyn' that is the name of a city in America. This word is categorized having a punctuation error because as the name of a city, Brooklyn should be initiated by a capital letter. However, it does not occur in SL. Similar phenomenon can be found in TL, the translator successfully maintains the element of this punctuation error. Therefore, this translation has a good score in terms of accuracy and acceptance.

\section{Grammatical error}

SL : He said Miss Kinniantolldhim I was her bestist pupil in the Beekman School for retarted adults and I tryed the hardistbecaus I reelywantd to lern 
I wantid it more even then pepul who are smarter even then me.

TL : Ia mengatakan Nona Kinnian bilang ggp adanya aku adalah murid tebaiiiknya di Sekolah Beekman untuk Orang Dewasa Terbelakang dan aku berusaha paling kueras krena aku btul-btul ingin blajar lebih banyak lagi dar ioragn-oragn yang lebih pandai dari aku sendiri.

In this datum, there is the word 'bestist' which means 'the best'. This datum is categorized having grammatical errors in term of comparison degree. However, the translator successfully maintains the autism marker word into TL. The technique is called established equivalent which results very good accuracy and acceptability.

\section{Translation by Compensation} Spelling error type 1

SL : My name is Charlie Gordon I werk in Donners bakery where $\mathrm{Mr}$ Donner gives me 11 dollers a week and bred or cake if I want.

TL : Namaku Charlie Gordon. Aku kreja di toko kwe Donners. Pak Donners menggajiku 11 dolar tiap minggu ditambah roti atau kwe jika aku mau.

In the following word there is a word 'bred' that contains spelling error that actually has a meaning bread. However in this case, the translator does not make a mistake on the word 'bred' but this word moves to the word 'cake' which translates to kwe. The spelling error in the word 'bred' is compensated to the word 'cake' which is translated as kwe. Therefore this translation technique is called compensation. This translation technique produces an accurate and acceptable translation. This is because the translator still retains the form of autism marker even though it is shifted to the other word.

\section{Spelling error type 2}

SL : So I said hello Miss Kinnian I'm redy for my lessen today only I lossed the book we was using.
TL : Maka aku berkata halo Nona Kinnian aku siap untuk blajar hari ini hanya aku khilangan buku yang kami pakai.

In this word the translator uses a compensation technique to translate the word 'lossed' which has a grammatical error and should be written into 'lost'. But, in this case, the translator moves a word containing a grammatical error into a word containing a spelling error.

\section{Spelling error type 3}

SL : Prof Nemur said but why did you want to lern to reed and spell in the frist place.

TL : Prof Nemur bilang tetapi mengapa kau ingin belajar mbaca dan mengja.

Here, the word 'frist' which means 'first' is omitted by the translator. In addition, the translator replaces the word that mark autism 'reed' and 'spell' into mbaca and mengja which means 'read' and 'spell'. This technique is called compensation, and it only appears in 3 data in this research.

\section{Punctuation error}

SL : What happind is I went to Prof Nemurs office on my lunch time like they said and his secertery took me to a place that said psych dept on the door with a long hall and alot of little rooms with onley a desk and chares.

TL: Begini critanya aku pergi ke kantor Prof Nemurs waktu jam makan siang seperti yang mereka minta dan seksertarisnya membawa aku ke tempat yang pintunya ada tulisan dept kejiwaan. Gang itu panjang dan banyak ruangan keicl yang hanyia berisi satu meja dan kursi-kursi.

In this datum, there is a word that is categorized having a punctuation error. The word 'a lot' which means 'a lot' is not written correctly by using a space. However, in TL the translator converts this punctuation error into a spelling error in the word keicl. Meanwhile, the word 'little' in SL does not contain any spelling error. This technique is called compensation. In 
this study, such a technique is only found once.

\section{Grammatical error}

SL : I said to myself Charlie if they make fun of you dont get sore because you remember their not so smart like you once thot they were.

TL : Kukatakan pada diriku sendiri Charlie jika mereka mengolokmu jagnan marah karena kau ingat mreka tidak sepandai dirimu walau mereka dulu beprikir begitu.

This datum is classified as a grammatical error, because there is a word 'their' which should be written 'they are'. So, it fails to apply the use of possessive pronoun in English. However, in the target language the translator transfers these grammatical elements into a spelling error mreka in the target language. This translation technique is called as compensation technique, and this also results in a good translation quality,which is still consideredaccurate and acceptable in the target language.

\section{Translation by Deletion}

\section{Spelling error type 1}

SL : He had a wite coat like a docter but I dont think he was no docter because he dint tell me to opin my mouth and say ah.

TL : Ia pake jas puith seperti doktre karena ia tidak bilang sama aku buka mulut dan bilang aaa...

In this translation, there is the word 'docter' which means 'doctor'. However, in this translation, the translator omits the word 'docter' which became the marker of autism. Therefore it can be concluded that this translation uses deletion technique. This technique causes its accuracy and acceptability as well as its readability to be low.

\section{Spelling error type 3}

SL : He had a wite coat like a docter but I dont think he was no docter because he dint tell me to opin my mouth and say ah.
TL : Ia pake jas puith seperti doktre karena ia tidak bilang sama aku buka mulut dan bilang aaa....

In this sentence there is a word 'no' which contains a spelling error, should be written with 'not'. But in this data, the translator omits the word 'no' which represents an autism marker. Hence, it is called deletion technique and causes a low score in terms of accuracy, acceptability, and readability of translation.

\section{Grammatical error}

SL : She started to cry and run out of the room and everybody looked at me and I saw a lot of them wasn't the same pepul who use to be in my class.

TL: Nona Kinnian mulai menangis dan berlari keluar ruangan lalu semua orang melihat kearahku dan aku melihat banyak dari mereka bukan oragn-oragn yang sama yang biasanya ada di kelas ini.

In this datum there is the word 'was not' which is classified as a word that contains a grammatical error in term of subject and verb agreement. This is because the subject in this sentence is 'a lot of them'. Therefore, it should use auxiliary verb be 'were' in English. However the translator omits this word in TL. Thus, the datum represents deletion technique which results in low accuracy, acceptability, and readability of the translation quality.

In this research, the most common type of error found is spelling errors followed by grammatical errors, and the last is punctuation errors. The translation techniques that are often used by the translator in translating the words marking autistic character are established equivalent (52.05\%), graphology normalization technique (41.08\%), for compensation technique $(4.53 \%)$, and the last is deletion technique $(0.96 \%)$.

\section{CONCLUSION}

From this research, it is found that translation which applies established equivalent technique results in a good 
translation quality with high scores in terms of accuracy and acceptability. As for the translation that apply graphology normalization technique, it produces a translation with a high accuracy. However, in terms of acceptability, it is quite low. This is caused by the fact that the translator eliminates the marker of autistic character in TL. On the other hand, compensation technique produces translations with good scores in terms of accuracy and acceptability. Meanwhile, for translation that use deletion technique, it produces a translation with low accuracy, acceptability, and readability.

From this research, it can be understood that translating literary works such as a novel needs a background and adaptation related to the theme and the context of the story. By understanding the novel well, there will be no shift in translation. Therefore, it is important for the translator to have a good comprehension of the context and the knowledge on the character with autism before translating the novel.

\section{REFERENCES}

Akhadiah. 1990. Pembinaan Kemampuan Menulis Bahasa Indonesia. Jakarta: Erlangga

Bailey, Eileen. 2011. Asperger Syndrome. Matrix Parent Network and Resource Center. autism-help.org

Bastian, Amy. 2007. "Autism and Motor Skills: A Matter of White Matter?" Journal of Neurology, 47(4): 448-460.

Brann, B. 1997. The Brann Analysis Grid for Spelling. Australia: PJ Developments

Cantwell, DP, L Baker \& RE Mattison. 1979. "The Prevalence of Psychiatric Disorder in Children with Speech and Language Disorder: An Epidiomologic Study". Journal of The American Academy of Child Psychiatry, 18: 450461.
Catford, JC. 1965. A Linguistic Theory of Translation. Oxford: Oxford University Press

Chaer, Abdul. 2009. Psikolinguistik: Kajian Teoritik. Jakarta: Rineka Cipta.

Christie, Phil. 2009. Langkah Awal Berinteraksi Dengan Anak Autis. Jakarta: Gramedia Pustaka Utama

Cook, Vivian. 1999. Teaching Spelling. http://privatewww.essex.ac.uk/ vcook/O BS2O.html

Cook, Vivian. 2014. The English Writing System. New York: Taylor \& Francis

Fay, L. 1971. "Reading and Spelling: How Are They Related?". ERIC Document Reproduction Service No. ED059009

Flood, A. 2014. Flowers for Algernon's Sad, Sweet Genius. https://www.theguardian. com/books/booksblog/2014/jun18/flowers -for-algernon-genius-daniel-keyes (Accessed November 5, 2017)

Ida, F. 2006. English Spelling in Swedish Secondary School: Students' Attitudes and Performance. Stockholm: Karlstads University

Kanner, L. 1968. "Autistic Disturbances of Affective Contact". Nerv Child 2: 21750. Reprint: Acta Paedopsychiatry, 35 (4): $100-36$

Larson, Mildred L. 1998. Meaning-based Translation: A Guide to Cross Language Equivalence. Lanham: University Press of America

Malmkjaer, K. 2005. Linguistics and the Language of Translation. Edinburgh: Edinburgh University Press Ltd.

Molina, L \& Albir, AH. 2002. "Translation Techniques Revisited: A Dynamic and Functionalist Approach". Meta: Translators' Journal, XLVII (4)

Moseley, D. 1993. How Lack of Confidence in Spelling Affects Children's Written Expression. Wellington: New Zealand Council for Educational Research

Nababan, MR. 2003. Teori Menerjemah Bahasa Inggris. Yogyakarta: Pustaka Pelajar

Nababan, MR. 2007. Aspek Genetik, Objektif, dan Afektif dalam Penelitian Penerjemahan. Surakarta: Universitas Sebelas Maret

Nababan, MR 2010. "Teknik-teknik Penerjemahan Teks". National Seminar 
of Translation Proceedings. Madiun: UniversitasWidya Mandala

Nababan, MR, Ardiana. N \& Sumardiono. 2012. "Pengembangan Model Penilaian Kualitas Terjemahan". Jurnal Kajian Linguistik dan Sastra, (24) 1: 39-57. Surakarta: Universitas Sebelas Maret.

Neubert, A. 2004. "Case Studies in Translation: The Study of Translation." Across Language and Culture, 5 (1): 521

Newmark, Peter. 1981. Approaches to Translation. Oxford: Pergamon Press

Newmark, Peter. 1988. A Textbook of Translation. London: Prentice Hall

Nida, Eugene A \& Taber, Charles R. 1974. The Theory and Practice of Translation. Leiden: United Bible Societies/EJ Brill

Nida, Eugene A \& Taber, Charles R. 1982. The Theory and Practice of Translation. Leiden: EJ Brill

Nida, Eugene. 2000. Principles of Correspondence in Translation Studies Reader. London: Routledge

Nurdiantoro, Burhan. 1991. Teori Pengkajian Fiksi. Yogyakarta: Gadjah Mada University Press

Retnomurti, Ayu Bandu \& Indiyah Imran. (...). The Equivalence and Shift in the English Translation of Indonesian Noun
Phrases. Jakarta: Universitas Gunadarma

Santosa, Riyadi. 2017. Buku Metode Penelitian Kualitatif Kebahasaan. Surakarta:UNS Press.

Smedley, D. 1983. Teaching the Basic Skills: Spelling, Punctuation, and Grammar in Secondary English. London: Methuen

Spradley, James P. 2007. Metode Etnografi. Yogyakarta: Tiara Wacara.

Sterling, Bruce. 2016. Science Fiction, Literature and Performance. London: Encyclopedia Britannica Press

Sutopo, Anam. 2016. "Model Penilaian Kualitas Terjemahan Karya Sastra". The 4th University Research Colloquium 2016. ISSN 2407-9189

Widdowson, Henry. 2004. "Text, Context, and Pretext". International Journal of Applied Linguistic

Willett, L. 2003. Using Spelling Data to Improve Students Learning Outcomes: More than Just Numbers. Brisbane: Australia-Queensland Studies

Wilkinson, David. 2000. The Researcher's Toolkit. London: Cambridge University

Wiratno, Tri. 2003. Analisis Bahasa dari Sudut Pandang Linguistik Sistemik Functional (Makalah). Surakarta: Universitas Sebelas Maret 